\title{
PELEMBAGAAN PERSPEKTIF MASYARAKAT SASAQ DALAM MENJAGA POTENSI KELAUTAN DI KAWASAN PESISIR TELUK JOR KABUPATEN LOMBOK TIMUR NUSA TENGGARA BARAT
}

Mey Susanti AS

Program Studi Ilmu Administrasi Negara, STIA Mataram, Nusa Tenggara Barat

meysusanti.as@gmail.com

ARTIKEL INFO
$\begin{aligned} & \text { ABSTRACT } \\ & \text { Keywords: } \begin{array}{l}\text { The existence of mangrove forest ecosystems in coastal areas usually } \\ \text { Perspectives, Local Wisdom, } \\ \text { Marine Potential. }\end{array}\end{aligned} \quad \begin{aligned} & \text { as desert-seagrass ecosystems, algae and coral reefs, thus forming a vast and } \\ & \text { very complex ecosystem. The conditions like this are also found on the coast } \\ & \text { of Teluk Jor, Jerowaru, East Lombok Regency, West Nusa Tenggara. The } \\ & \text { absence of regulation of resource use is a problem in Teluk Jor which starts } \\ & \text { from the people's perception of marine and fisheries resources as public } \\ & \text { property, joint property or individual property. This studies aims to see the } \\ & \text { extent of the awiq-awiq role and the effectiveness of its implementation in } \\ & \text { developing the coastal community of Teluk Jor. The research method used is } \\ & \text { a qualitative method, with a phenomenological perspective. The results of the } \\ & \text { identification shows that awiq-awiq Teluk Jor is formed from local wisdom } \\ & \text { and community initiation to conserve the areas. }\end{aligned}$

\section{PENDAHULUAN}

Wilayah laut lndonesia seluas 5,8 juta $\mathrm{km} 2$ adalah fakta fisik yang tak terbantahkan, ditaburi dengan 17.500 lebih pulau, dan dirangkai oleh garis pantai sepanjang $81.000 \mathrm{~km}$ yang merupakan garis pantai terpanjang kedua di dunia setelah Kanada. Bentangan jarak dari wilayah darat di ujung barat (Sabang) ke ujung timur (Merauke) sebanding dengan dari London (barat) sampai ke Baghdad (timur). Sedangkan rentang wilayah darat dari ujung utara (Pulau Miangas, Kabupaten Sangihe Talaud) sampai ke ujung selatan (Pulau Rote) hampir sama dengan jarak antara utara di Jerman hingga ke selatan di Aljajair (Soegondo dalam Suryanegara, 2000). Lebih dari itu, laut beserta kawasan pesisir yang mengitarinya mengandung potensi ekonomi (pembangunan) yang sangat besar dan beraneka-ragam.

Indonesia sebagai negara maritim, di mana pada kawasan tersebut terdapat berbagai macam tipe vegetasi dan salah satu di antaranya adalah hutan mangrove. Hutan mangrove didefinisikan sebagai suatu ekosistem yang terdiri dari gabungan komponen daratan dan komponen laut, di mana termasuk di dalamnya adalah flora dan fauna yang hidup saling bergantung satu dengan lainnya. Keberadaan ekosistem hutan mangrove di wilayah pesisir biasanya tumbuh dan berkembang bukanlah sendirian, namun berkaitan erat dengan ekosistem lainnya, seperti ekosistem padang-lamun, algae dan terumbu karang, sehingga membentuk suatu ekosistem yang lebih luas dan sangat kompleks. Kondisi seperti ini juga ditemukan di pesisir Teluk Jor, Jerowaru Kabupaten Lombok Timur, Nusa Tenggara Barat.

Laut Lombok Timur memiliki potensi sumber daya ikan lestari (MSY-Maximum Sustainable Yield) sebesar 18.242 ton/tahun yang terdiri dari potensi sumber daya ikan pelagis 7.752,8 ton/tahun dan potensi sumber daya ikan demersal $10.489,2$ ton/tahun. Selain potensi perikanan tangkap, laut Lombok Timur juga potensial untuk kegiatan budidaya laut yaitu mutiara, ikan kerapu, udang lobster, rumput laut, teripang dan kekerangan. Potensi budidaya mutiara 3.433,65 ha, ikan kerapu 509,40 ha, udang lobster 525,68 ha, rumput laut 2.000 ha, teripang 194 ha, dan kekerangan 179,5 ha (Kemeterian Kelautan dan Perikanan 2008).

Kabupaten Lombok Timur memiliki panjang pantai $220 \mathrm{~km}$ dan memiliki lingkungan ekosistem hutan bakau (mangrove) dengan luas $1.589,81$ ha yang tersebar pada wilayah Kecamatan Jerowaru, Keruak, Pringgabaya dan Sambelia (Perda Lombok Timur No 10, 2006). Mangrove yang tumbuh di 
sekitar Teluk Jor berjenis sonneratia yang merupakan jenis pionir, berupa pohon berukuran sedang hingga besar. Sonneratia lebih dikenal dengan nama Pedada atau Pining dalam sebutan masyarakat di sekitar Teluk Jor, adalah jenis mangrove yang buahnya bisa dimakan dan bisa juga dibuat menjadi minuman segar.

Perairan Teluk Jor merupakan perairan berstatus daerah pemanfaatan yang diperuntukkan untuk pengembangan perikanan budidaya, dengan memanfaatkan kondisi perairan dan teknologi karamba jaring apung (KJA) sebagai media pembesaran. Dari kegiatan perikanan tangkap masyarakat Teluk Jor, sebagian hasil tangkapan khususnya adalah udang rebon (udang masin) yang kemudian diolah menjadi terasi. Hampir setiap rumah khususnya di Desa Jerowaru memiliki usaha Pembuatan Terasi Udang Murni. Produksi dilakukan warga di rumah mereka mulai dari penyeleksian udang, penggilingan, hingga proses pengeringan. Rasa udang mereka nomor satu di Lombok sebab model pembuatannya yang tanpa pengawet, tanpa pewarna bahkan tanpa garam. Produksi kelompok pengolahan terasi per minggu 20-30 kg dengan bahan baku rebon sekitar 100-200 kg. Kelompok pengolahan terasi terdiri dari 10 anggota. Di desa Teluk Jor sendiri terdapat sejumlah pengusaha terasi dengan memberdayakan ibu-ibu rumah tangga sekitar. Secara ekonomi dan pemasaran, produk terasi kelompok ini sudah mulai mengembangkan merk (branding) dan sudah mengajukan ijin PIRT serta labeling produk.

Dari beberapa catatan disebutkan, bahwa perusakan lingkungan laut di Teluk Jor sudah terjadi sejak tahun 1960-an. Konflik terbuka antar warga di dusun-dusun yang berbatasan dengan Teluk Jor dengan pemicu yang bermacam-macam. Mulai soal pemasangan keramba jaring apung di jalur lintas pelayaran, perebutan area penangkapan ikan, hingga penggunaan alat lampu yang terlampau terang. Tak adanya pengaturan pemanfaatan sumber daya adalah masalah di Teluk Jor yang dimulai dari persepsi masyarakat terhadap sumber daya kelautan dan perikanan sebagai milik umum, milik bersama atau milik individu. Tanpa konsepsi kepemilikan yang jelas atas sumber daya kelautan dan perikanan, setiap orang cenderung akan bersaing mengambil hasil sumber daya kelautan dan perikanan sebanyak-banyaknya dan secepat-cepatnya yang menimbulkan kerusakan lingkungan dan konflik dalam pemanfaatannya.

Awiq-awiq yang merupakan kearifan lokal membentuk kebijakan berupa norma, berisi tentang larangan dan sanksi tertulis dan tidak tertulis mengenai pengelolaan sektor perikanan pantai. Penelitian kelembagaan awiq-awiq Teluk Jor ini dilakukan untuk melihat sejauhmana peran dari awiq-awiq tersebut dan bagaimana efektivitas implementasi awiq-awiq dalam pengembangan pelembagaan masyarakat pesisir Teluk Jor guna meningkatkan partisipasi masyarakat dalam pengambilan keputusan dan pengawasan pengelolaan potensi sumber daya.

Pelembagaan (institutionalization) terdiri dari penetapan norma-norma yang pasti yang menentukan posisi status dan fungsi peranan untuk perilaku. Pelembagaan mencakup penggantian perilaku spontan atau eksperimental dengan perilaku yang diharapkan, dipolakan, teratur dan dapat diramalkan.

Menurut Koentjaraningrat, institusi sosial adalah suatu norma khusus yang menata serangkaian tindakan yang berpola untuk keperluan khusus manusia dalam kehidupan masyarakat. Institusionalisasi atau pelembagaan adalah aturan-aturan penetapan norma-norma yang menentukan posisi, status, dan fungsi peranan perilaku. Menurut Cohen (1983) institusionalisasi adalah perkembangan sistem yang teratur dalam norma-norma, peranan yang diterapkan dan diterima oleh masyarakat.

Menurut para ahli; Martono 2010: perspektif merupakan cara pandang terhadap suatu masalah yang terjadi, atau sudut pandang tertentu yang digunakan dalam melihat suatu fenomena. Menurut Ardianto 2007: perspektif adalah cara pandang atau sudut pandang kita terhadap sesuatu. Menurut Joel M. Charon: perspektif adalah kerangka konseptual, perangkat asumsi, perangkat nilai dan perangkat gagasan yang mempengaruhi persepsi seseorang sehingga pada akhirnya akan mempengaruhi tindakan seseorang dalam situasi tertentu. Jadi perspektif atau sudut pandang yang dapat diartikan sebagai cara seseorang dalam menilai sesuatu yang bisa dipaparkan baik secara lisan dan tulisan.

Kearifan lokal adalah identitas atau kepribadian budaya sebuah bangsa yang menyebabkan bangsa tersebut mampu menyerap, bahkan mengolah kebudayaan yang berasal dari luar/bangsa lain menjadi watak dan kemampuan sendiri Wibowo (2015:17). Identitas dan Kepribadian tersebut tentunya menyesuaikan dengan pandangan hidup masyarakat sekitar agar tidak terjadi pergesaran 
nilai-nilai. Dalam bahasa asing sering juga dikonsepsikan sebagai kebijakan setempat local wisdom atau pengetahuan setempat "local knowledge" atau kecerdasan setempat Fajarini (2014:123).

Hal senada juga diungkapkan oleh Alfian (2013: 428) Kearifan lokal diartikan sebagai pandangan hidup dan pengetahuan serta sebagai strategi kehidupan yang berwujud aktifitas yang dilakukan oleh masyarakat lokal dalam memenuhi kebutuhan mereka. Berdasarkan pendapat Alfian itu dengan kata lain bahwa kearifan lokal merupakan adat dan kebiasaan yang telah mentradisi dilakukan oleh sekelompok masyarakat secara turun-temurun yang hingga saat ini masih dipertahankan keberadaannya oleh masyarakat hukum adat tertentu di daerah tertentu.

Berdasarkan pengertian di atas dapat diartikan bahwa local wisdom (kearifan lokal) dapat dipahami sebagai gagasan-gagasan setempat lokal yang bersifat bijaksana, penuh kearifan, bernilai baik, yang tertanam dan diikuti oleh anggota masyarakatnya.

Modal sosial termasuk konsep yang tidak gampang diidentifikasi apalagi diukur secara kuantitas dan absolut. Modal sosial dapat didiskusikan dalam konteks komunitas yang kuat (strong community), masyarakat madani yang kokoh, maupun identitas negara-bangsa (nation-state identity). Modal sosial termasuk elemen-elemennya seperti kepercayaan, kohesivitas, altruisme, gotong-royong, jaringan, dan kolaborasi sosial memiliki pengaruh yang besar terhadap pertumbuhan ekonomi melalui beragam mekanisme, seperti meningkatnya rasa tanggung jawab terhadap kepentingan publik, meluasnya partisipasi dalam proses demokrasi, menguatnya keserasian masyarakat dan menurunnya tingkat kekerasan dan kejahatan (Blakelley dan Suggate, 1997 dalam Suharto, 2006).

Menurut Hasbullah (2006), modal sosial adalah jumlah sumber-sumber daya, aktual atau virtual (tersirat) yang berkembang pada seorang individu atau sekelompok individu karena kemampuan untuk memiliki suatu jaringan yang dapat bertahan lama dalam hubungan-hubungan yang lebih kurang telah diinstitusikan berdasarkan pengetahuan dan pengenalan timbal balik. Menurut Partha dan Ismail (2009), modal sosial merupakan hubungan-hubungan yang tercipta dan norma-norma yang membentuk kualitas dan kuantitas hubungan sosial dalam masyarakat dalam spektrum yang luas, yaitu sebagai perekat sosial (social glue) yang menjaga kesatuan anggota kelompok secara bersama-sama, kemudian menurut Prusak L (Field, 2010:26), modal sosial adalah hubungan yang terjadi dan diikat oleh suatu kepercayaan (trust), saling pengertian (mutual understanding), dan nilai-nilai bersama (shared value) yang mengikat anggota kelompok untuk membuat kemungkinan aksi bersama secara efisien dan efektif.

\section{METODE}

Penelitian ini menggunakan metode kualitatif. Menurut Jane Richie dalam Moleong (2001:6) penelitian kualitatif adalah upaya untuk menyajikan dunia sosial, dan perspektifnya di dalam dunia dari segi konsep, perilaku, persepsi dan persoalan tentang manusia yang diteliti. Salah satu perspektif yang digunakan dalam penelitian kualitatif adalah perspektif fenomenologi. Penggunaan perspektif fenomenologi ini dimaksudkan untuk merekonstruksi kehidupan manusia ke dalam bentuk yang mereka alami sendiri.

Proses Pendekatan dalam penelitian adalah pada model A Data Collecting Circle dari Creswell, proses pendekatan ini disebut sebagai Gaining Access and Making Rapport. Peneliti melakukan pendekatan dengan bertemu dan mendatangi langsung subyek atau informan. Saat bertemu peneliti mencoba berkomunikasi secara informal sampai akhirnya peneliti menyampaikan maksud dan tujuan peneliti terhadap informan tersebut.

Untuk pemilihan informan menurut Cresswell dalam Kuswarno (2009:132) kriteria informan yang baik adalah: "all individuals studied represent people who have experienced the phenomenon" (Creswell, 2018:118). Jadi, peneliti memilih informan yang benar-benar mampu mengartikulasikan pengalaman dan pandangannya tentang sesuatu yang ditanyakan, dapat memberikan informasi yang relevan dan dapat membantu menjawab pertanyaan dari peneliti. Teknik pengumpulan data dilakukan dengan cara: (1) Observasi; (2) Wawancara Tak Terstruktur atau wawancara mendalam (in-depth interview); (3) Studi Dokumentasi.

Prosedur pencatatan data dilakukan melalui wawancara mendalam dan dilakukan setelah wawancara selesai dan direkam dengan menggunakan alat perekam (tape recorder). Isu-isu lapangan diperlukan dengan tujuan untuk merekam beberapa kejadian ketika sedang melakukan pengamatan. Selain dimulai dengan mempersiapkan pedoman melakukan pengamatan, pada tahap ini 
diperlukan juga aktivitas pencatatan kejadian-kejadian yang berkaitan dengan isu yang menjadi pokok dalam penelitian ini. Sebagaimana yang dikatakan Humphrey dalam Kuswarno (2009: 74), dalam metode penelitian fenomenologi, teknik validasi data dilakukan dengan mengirimkan hasil penelitian kepada masing-masing informan, dan meminta mereka untuk mengoreksi atau memberikan masukan.

\section{HASIL DAN PEMBAHASAN}

Kabupaten Lombok Timur adalah salah satu kabupaten di Provinsi Nusa Tenggara Barat. Berada di sebelah timur Pulau Lombok, dengan letak geografis antara $116^{\circ}-117^{\circ}$ Bujur Timur dan $8^{\circ}$ $9^{\circ}$ Lintang Selatan. Luas wilayahnya tercatat $2.679,88 \mathrm{~km} 2$, terdiri atas daratan seluas $1.605,55 \mathrm{~km} 2$ atau $(59,91 \%)$ dan lautan seluas $1.074,33 \mathrm{~km} 2(40,09 \%)$. Secara administratif Kabupaten Lombok Timur terdiri dari 20 kecamatan, 13 kelurahan, 106 Desa, 772 lingkungan/dusun. Dengan batas administrasi sebagai berikut sebelah Utara dengan Laut Jawa, sebelah Selatan dengan Samudra Indonesia, sebelah Barat dengan Kabupaten Lombok Tengah, sebelah Timur dengan Selat Alas (BPS Kabupaten Lombok Timur 2013).

Masyarakat Sasaq sebagai masyarakat asli yang mendiami Pulau Lombok memiliki hubungan yang erat dengan laut. Dalam Lontar Kotaragama, jaladri (laut) adalah sifat yang harus dipunyai seorang raja, agar seorang raja bagaikan laut, menampung segala aspirasi dan meredam bau amis dan busuk.

Awiq-awiq sebagai kearifan lokal mengatur hubungan antar manusia dengan manusia, manusia dengan alam serta manusia dengan Pencipta. Dan pada hakikatnya merupakan aturan lokal sebagai hak masyarakat untuk mengatur lingkungannya sendiri dan menjadi aturan atau kesepakatan yang dibuat untuk dijalankan dan ditaati bersama. Secara bahasa, awiq-awiq berasal dari kata "wiq" yang berarti rusak, sementara "awiq" artinya tidak rusak atau baik. Secara harfiah, awiq-awiq dimaknai sebagai ketentuan atau tata krama pergaulan hidup dalam masyarakat untuk mewujudkan tata kehidupan yang lebih baik.

Sejak tahun 2013, Awiq-awiq pengelolaan kawasan Teluk Jor telah ditetapkan bersama oleh para pemangku kepentingan di kawasan tersebut. Awiq-awiq merupakan aturan adat yang disepakati oleh 2 desa yaitu Desa Jero Waru dan Desa Pare Mas, Kabupaten Lombok Timur. Awiq-awiq ini diinisiasi oleh masyarakat dan 8 kepala kampung yang didampingi Lembaga Pengembangan Sumber Daya Nelayan (LPSDN) selama 3-4 bulan karena keresahan atas kondisi Teluk Jor yang semakin kurang baik.

Bersamaan dengan ditetapkannya Awiq-awiq tersebut juga ditetapkan Lembaga Pemangku Awiq-awiq Teluk Jor (LPATJ) sebagai lembaga yang mengawal pelaksanaan aturan adat tersebut secara legitimasi, LPATJ merupakan cerminan kerjasama antar desa yang dituangkan dalam kesepakatan bersama 2 (dua) desa yaitu Desa Jero Waru dan Desa Pare Mas. Secara aktual, LPATJ memiliki anggota sebanyak 17 kelompok di mana masing-masing kelompok terdiri dari 10-15 orang. Kelompok-kelompok tersebut merupakan kelompok perikanan tangkap, kelompok pengolahan dan kelompok keramba jaring apung (KJA).

Aktivitas utama LPATJ adalah 1) Melakukan pengawasan dan patroli di kawasan Teluk Jor; 2) Pengelolaan Mangrove; 3) Sosialisasi Awiq-awiq melalui papan pengumuman di tempat pendaratan perahu dan sosialisasi rutin Awiq-awiq di masjid-masjid dan juga melalui kader kesehatan; 4) Pendampingan dan penguatan kapasitas kelompok agar memahami Awiq-awiq.

Modal sosial yang dimiliki lembaga ini cukup baik. Selain pertemuan bulanan sebagai media koordinasi dan komunikasi pengurus, pemilik bagan dan KJA, juga memberikan iuran untuk membantu operasional patroli keamanan yang dilakukan oleh LPATJ. Selain itu, secara umum gotong-royong di wilayah ini masih cukup baik.

Perumusan awiq-awiq dilakukan melalui konsultasi publik dengan masyarakat di tingkat dusun. Setelah melalui konsultasi publik di tingkat dusun, perumusan awiq-awiq dilanjutkan dengan lokakarya tingkat desa, dan terakhir lokakarya tingkat kecamatan. Setelah rancangan awiqawiq selesai, hasilnya disosialisasikan kepada masyarakat. Setelah melalui proses pembahasan dari Juni hingga September 2013, akhirnya pada 28 November 2013 disepakati awiq-awiq Kawasan Teluk Jor Kecamatan Jerowaru Kabupaten Lombok Timur Tentang Pengelolaan Sumber daya Ikan. Awiq-awiq dituangkan dalam bentuk peraturan bersama Masyarakat Kawasan Teluk Jor 
Desa Jerowaru Dan Desa Pare Mas yang ditanda tangani oleh Ketua Badan Permusyawaratan Desa serta Kepala Desa dari Desa Jerowaru dan Desa Pare Mas yang diketahui oleh Camat Jerowaru. Ketentuan mengenai keberlakuan dari awiq-awiq Teluk Jor baru dimulai tiga bulan setelah disahkan.

Awiq-awiq ini terbagi dalam 13 bab dan terdiri dari 17 pasal. Bab-bab tersebut mengatur ketentuan umum, jenis dan sarana alat penangkapan ikan, wilayah penangkapan ikan dan pengoperasian alat penangkapan ikan, budidaya, konservasi, pencemaran lingkungan pesisir, keamanan, pelayaran, kelembagaan dan sumber dana pengelolaan, sanksi, prosedur pemberian sanksi, aturan tambahan dan peralihan dan penutup. Terkait dengan konservasi, awiq-awiq mengatur pemanfaatan mangrove untuk penelitian, pariwisata dan kegiatan usaha yang tidak merusak serta perlindungan dari penebangan dan konversi menjadi tambak.

Awiq-awiq Teluk Jor memiliki sistem kelembagaan dalam menjalankan fungsi dan tugasnya. Hal ini diperlukan untuk menjaga ketertiban masyarakat nelayan dalam hal mengatur tata cara penangkapan ikan, pemeliharaan sumber daya ikan serta menjaga lingkungan untuk ketentraman hidup masyarakat nelayan di wilayah tersebut. Sistem kelembagaan yang terdiri dari batasan wilayah pengelolaan, sistem organisasi, sistem aturan, sistem sanksi, dan legalitas. Berikut merupakan penjelasan lebih rinci tentang sistem kelembagaan awiq-awiq Teluk Jor terdapat pada lampiran.

1) Batas wilayah pengelolaan, Kawasan Teluk Jor adalah wilayah pesisir, perairan dalam dan perairan luar. Teluk Jor secara administratif berada dalam wilayah kewenangan Desa Jerowaru dan Desa Paremas, Kecamatan Jerowaru. Perairan dalam adalah wilayah laut Teluk Jor dari Lis sampai ujung luar Gili Nunse. Perairan luar adalah wilayah laut Teluk Jor mulai dari titik terluar Gili Nunse sampai batas wilayah Desa Maringkik (Selat Gilli Kuri); 2) Sistem Organisasi, Pelaksanaan pengelolaan sumberdaya perikanan di kawasan Teluk Jor dilakukan oleh Lembaga Pemangku Awiq-Awiq Teluk Jor (LPATJ) di tingkat kawasan. LPATJ memiliki visi, misi, fungsi serta tujuan dalam pengelolaan perikanan di Teluk Jor. Visi dan misi dari LPATJ adalah melarang, mencegah serta memberantas semua kegiatan yang mengancam keselamatan ekosistem pesisir dan laut Teluk Jor. Tujuan LPATJ adalah ikut menjaga Teluk Jor agar tetap aman dan terkendali dari cara-cara penangkapan yang tidak ramah lingkungan. Pada sektor ekonomi, masyarakat menjadi lebih baik karena hasil yang diperoleh meningkat.

Fungsi LPATJ adalah a.) Sebagai wadah proses pembelajaran untuk meningkatkan kemampuan dan kemandirian masyarakat dalam menjaga dan mengelola sumber daya ekosistem pesisir dan laut; b.) Membangun dan menjalin kerjasama lembaga dengan pihak lain yang saling menguntungkan; c.) Unit penyedia sarana dan prasarana produksi perikanan yang dimanfatkan oleh masyarakat; d.) Unit produksi perikanan dari hasil tangkapan masyarakat nelayan; e.) Unit pengolahan dan pemasaran hasil laut sebagai tindak lanjut dari upaya peningkatan pendapatan serta kesejahteraan ekonomi rumah tangga; f.) Unit jasa penunjang adalah lembaga akan menyediakan fasilitas sarana antar jemput bagi pengunjung yang akan melakukan rekreasi ketempat-tempat wisata; g.) Kebutuhan lain yang bisa terjangkau oleh fasilitas yang ada kesatuan swadaya dan swadana untuk memajukan tujuan dan cita-cita lembaga.

Tugas dan wewenang LPATJ mengkordinir semua pengelolaan kawasan Teluk Jor yang diantaranya meliputi:

a. Meregistrasi semua kegiatan pemanfaatan keberlanjutan di kawasan Teluk Jor; b. Menjaga dan mengawasi sumberdaya perikanan yang berada di wilayah Teluk Jor; c. Melaksanakan atau menegakkan awiq-awiq; d. Mengkordinasi sumbangan dana dari masyarakat sesuai dengan ketentuan awiq-awiq; e. Memberikan masukan dalam rangka penyempurnaan dan pembentukan awiqawiq dalam waktu yang akan datang. Berikut Stuktur Organisasi Lembaga Pemangku Awiq-Awiq Teluk Jor yang ditunjukkan pada Gambar 1: 
Gambar 1. STRUKTUR ORGANISASI

LEMBAGA PEMANGKU AWIQ-AWIQ TELUK JOR

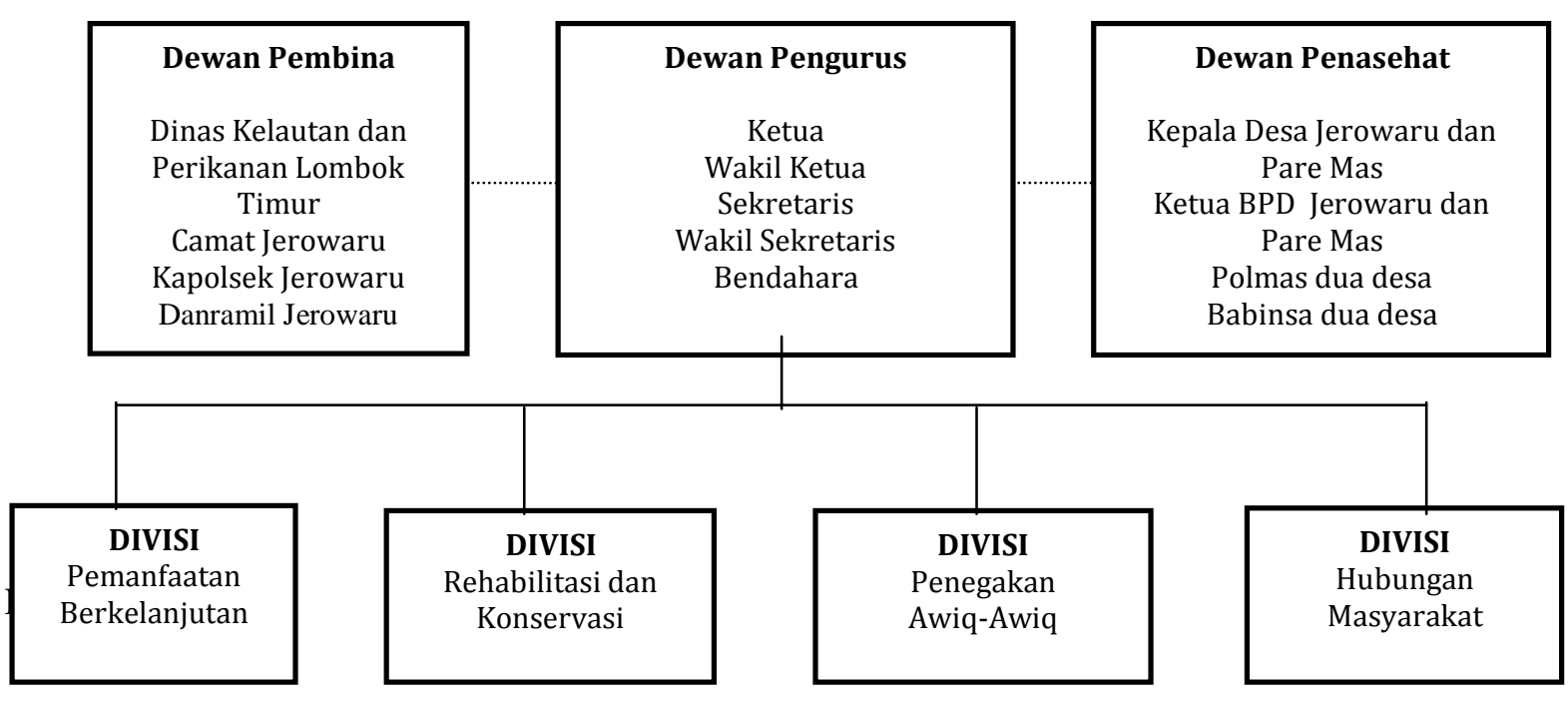

Awiq-awiq Teluk Jor menerapkan aturan terkait konservasi, khususnya mangrove, sebagaimana berikut:

1) Dilarang menebang dan merusak pohon mangrove di semua wilayah pesisir Teluk Jor.

2) Tidak diperbolehkan bagi setiap orang untuk membangun tambak di sepadan pantai yang masih menjadi lahan umum.

3) Pemanfaatan lahan mangrove terbatas hanya untuk penelitian, pariwisata dan atau kegiatan usaha lainnya yang tidak merusak mangrove.

Dalam pelaksanaan awiq awiq pada bab ini sudah berjalan sesuai dengan ketentuan yang ada dan kondisi hutan mangrove bisa terjaga dengan baik. Untuk pemanfaatan sebagai lokasi penelitian dan destinasi wisata, belum banyak dimanfaatkan, terlebih untuk pariwisata, sehingga sangat perlu adanya pengelolaan wisata yang terorganisir yang dapat menunjang perekonomian masyarakat kawasan.

Siput merupakan salah satu komoditas tangkapan nelayan di Teluk Jor ketika musim paceklik. Selain dijual secara langsung, siput juga sering dijadikan makanan olahan yang lebih bernilai. Namun siapa sangka siput juga menghasilkan limbah, yakni dari kulitnya yang sudah tidak dipakai. Hasil tangkapan siput oleh nelayan, setiap minggunya menyisakan limbah cangkang. Jumlah yang tidak sedikit ini tentu akan menjadi masalah baru bila tidak segera dicarikan solusi.

Terkait pencemaran lingkungan, awiq-awiq Teluk Jor mengatur sebagaimana berikut:

1) Setiap petambak, pada saat melakukan persiapan dan pencucian tambak tidak boleh menggunakan pestisida.

2) Setiap orang dan atau pembudidaya dilarang keras melakukan tindakan pembuangan limbah cangkang siput/keong di wilayah pesisir Teluk Jor.

3) Setiap orang dan atau pembudidaya yang menggunakan pakan kerang diwajibkan untuk menghancurkan limbah cangkang kerang/siput/keong dan membuangnya di tempat sampah yang telah disediakan sendiri sepanjang lokasi pembuangan tidak mengganggu lingkungan.

4) Dilarang keras melakukan tindakan pembuangan sampah di pesisir pantai.

Pada kenyataannya, ketentuan dari ayat

(2), (3), dan (4) belum berjalan atau diindikasikan terjadi pelanggaran berdasarkan hasil identifikasi dilapangan sebagai berikut :

1. Masih ada pembuangan limbah cangkang siput maupun sampah organik dan anorganik di wilayah pesisir Teluk Jor.

2. Dari identifikasi pertama terlihat bahwa proses penghancuran limbah cangkang siput sesuai dengan awiq awiq, belum berjalan.

3. Sanksi-sanksi yang tertera pada awiq-awiq belum diberlakukan. 
LPATJ memiliki sanksi bagi masyarakat yang melakukan pelanggaran hukum dalam hal konservasi mangrove dan pencemaran limbah lingkungan pesisir. Secara detail terdapat pada tabel berikut:

Tabel 1. Jenis Pelanggaran dan Sanksi dalam Konservasi Mangrove dan Pencemaran Limbah

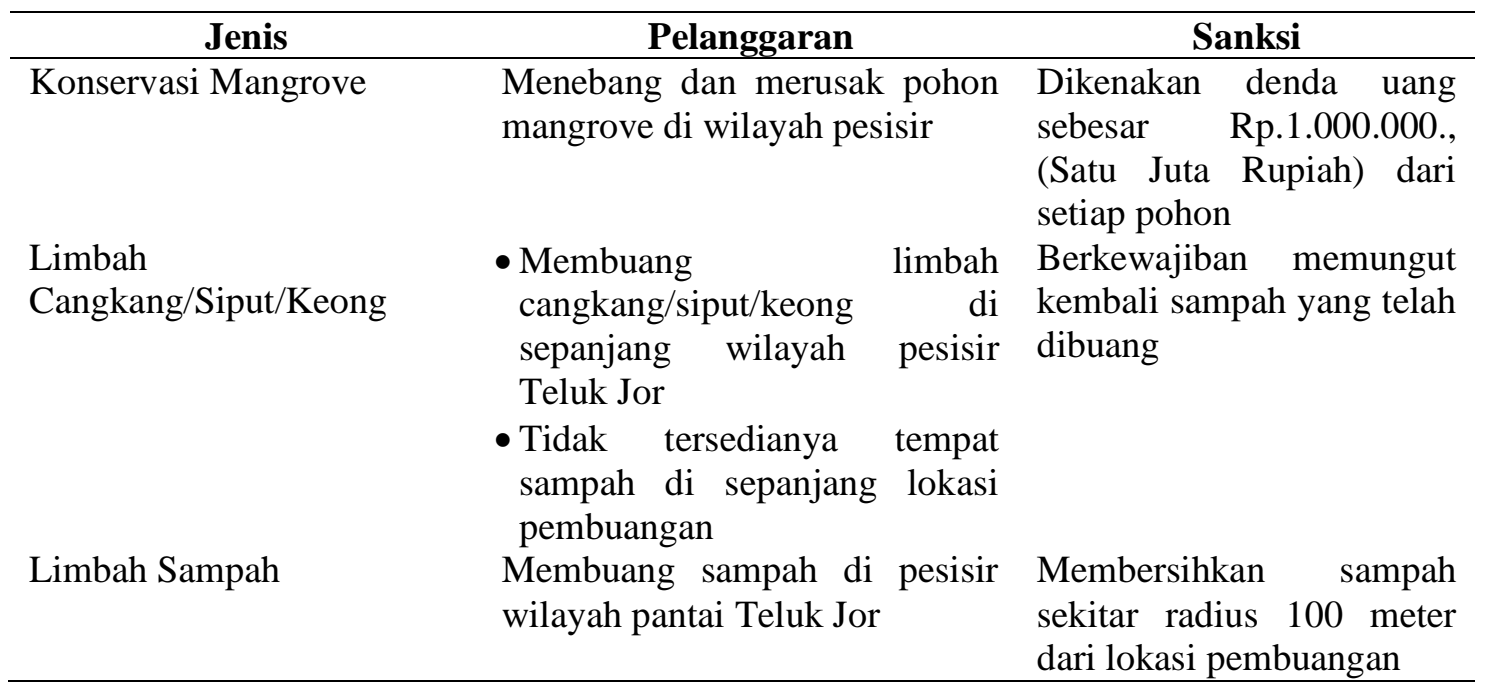

(Sumber: LPATJ 2016)

Pembuangan Limbah Cangkang Siput/Keong di Wilayah Pesisir Teluk Jor disajikan dalam Gambar 2:

Gambar 2. Pembuangan Limbah Cangkang Siput/Keong di Wilayah Pesisir Teluk Jor

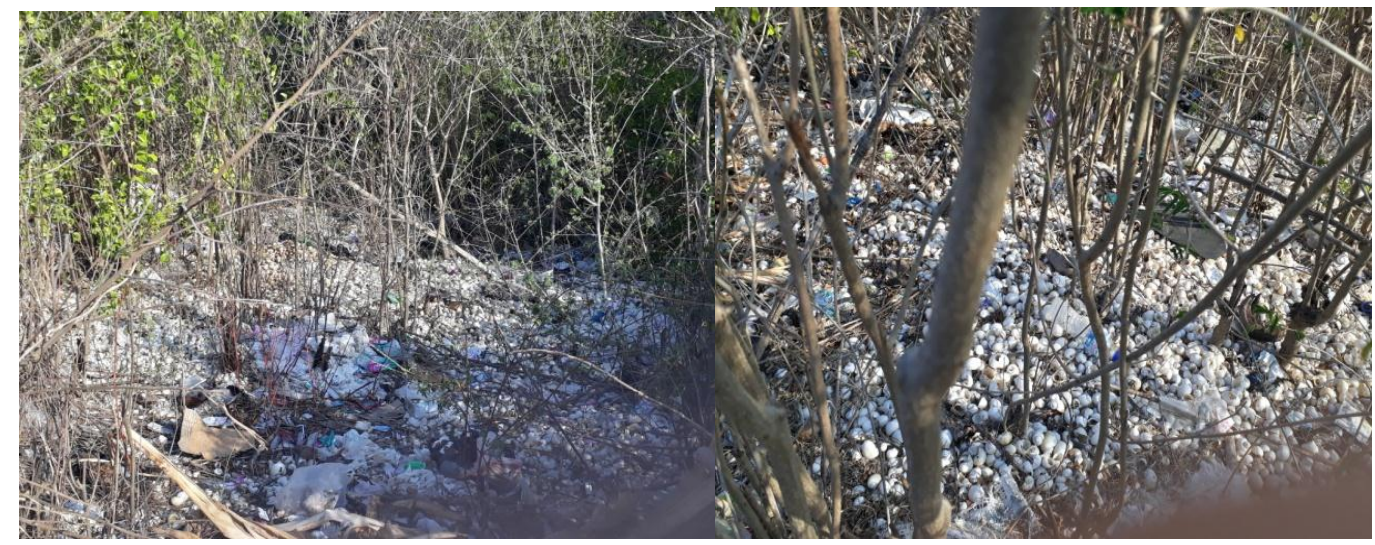

(Sumber: Dokumen Pribadi, 2018).

Agar limbah cangkang siput/keong tidak hanya menjadi barang tidak berguna, dapat dimanfaatkan untuk berbagai produk kerajinan dan hiasan. Pemanfaatan limbah kulit kerang ini hendaknya menjadi pemikiran pemerintah bersama nelayan, misalnya melalui kegiatan pengolahan limbah sehingga dapat memberikan penambahan ekonomi para nelayan.

Perilaku membuang sampah sembarangan di masyarakat sekitar Teluk Jor hampir menjadi budaya keseharian. Ditambah pula tidak didukung dengan infrastruktur tempat pembuangan sampah sementara dan pengelolaan sampah yang baik, sehingga banyak ditemukan plastik bekas deterjen dan sampah organik berserakan di sekitar perairan Teluk Jor. Perairan Teluk Jor dianggap oleh masyarakat sebagai perairan open access yang boleh dimanfaatkan sesuai ego masing-masing masyarakat. Apalagi perairan Teluk Jor dijadikan alternatif terakhir masyarakat dalam memenuhi kebutuhan ekonomi. 


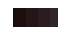

Gambar 3. Buangan Sampah di Pesisir Pantai Teluk Jor

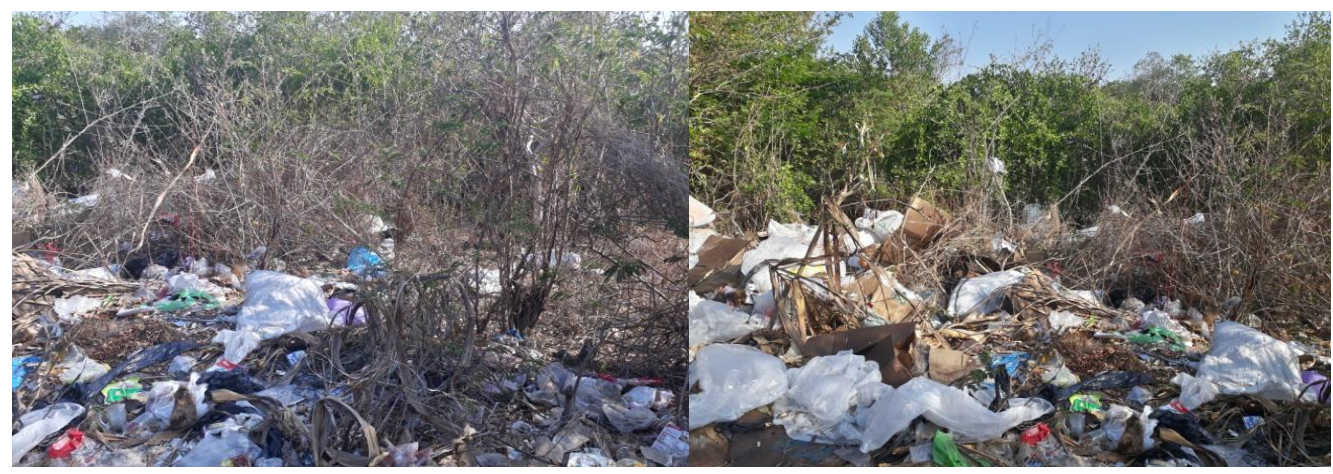

(Sumber: Dokumen Pribadi, 2018).KESIMPULAN

Awiq-awiq Teluk Jor terbentuk dari kearifan lokal dan inisiasi masyarakat pada tahun 2013 yang disahkan oleh perwakilan desa dan camat Jerowaru.

Strategi yang perlu dilakukan adalah penguatan kelembagaan LPATJ sehingga LPATJ dapat beroperasi dan memberikan pelayanan kepada kelompok-kelompok yang menjadi anggotanya (17 kelompok) secara maksimal yang telah terbentuk sejak tahun 2000, sehingga memiliki nilai tawar dalam melakukan perubahan kebijakan dan perubahan perilaku sosial masyarakat.

Kegiatan yang dapat dilakukan di dalam kelompok masyarakat melalui peningkatan kesadaran lingkungan, memperbaiki saluran pembuangan limbah penduduk agar tidak langsung masuk perairan, melakukan pelatihan teknis budidaya, melakukan kerjasama (MoU) dengan instansi terkait dalam hal pengelolaan perairan Teluk Jor yang berkelanjutan, melakukan sosialisasi dampak lingkungan dengan membuat papan larangan, kegiatan konservasi, kampanye lingkungan hidup ke instansi pendidikan dan membuat brosur/iklan.

\section{DAFTAR PUSTAKA}

BPS Kabupaten Lombok Timur 2013.

Kemeterian Kelautan dan Perikanan 2008.

LPATJ, 2016, Data Awig-Awig Teluk Jor.

Perda Lombok Timur No. 10 Tahun 2006.

\section{Jurnal}

Alfian, Magdalia, 2013, Potensi Kearifan Lokal dalam Pembentukan Jatidiri Dan Karakter Bangsa, Yogyakarta.

Burhanuddin, 2016, Pengelolaan Pesisir Teluk Jor Bagi Pengembangan Budidaya Karamba Jaring Apung Dengan Analisis Daya Dukung, Sekolah Pascasarjana, Institut Pertanian Bogor, Bogor.

Ditapa, Sukma, 2017, Kelembagaan Awig-Awig Dalam Pengelolaan Perikanan Tangkap Di Teluk Jor

Kabupaten Lombok Timur, Departemen Pemanfaatan Sumberdaya Perikanan Fakultas Perikanan dan Ilmu Kelautan Institut Pertanian Bogor, Bogor.

Fajarini, Ulfah. 2014, Peranan Kearifan Lokal Dalam Pendidikan Karakter, Jurnal Sosio Didaktika, Vol. 1, No. 2. Hal: 123-130.

Hasbullah J, 2006, Social Capital: Menuju Keunggulan Budaya Manusia Indonesia. MR-United Press Jakarta.

Istiawati, Fitri Novia, 2016, Pendidikan Karakter Berbasis Nilai-Nilai Kearifan Lokal Adat Ammatoa dalam Menumbuhkan Karakter Konservasi, Cendekia, 10(1): 1-18.

Oni Veriasa, Thomas, 2016, Kajian Kelembagaan Untuk Pengelolaan Pengetahuan Pembangunan Sumberdaya Pesisir Rendah Emisi, Proyek Pengelolaan Pengetahuan Wilayah Pesisir Rendah 
Emisi di Nusa Tenggara Barat dan Nusa Tenggara Timur, Konsorsium Karbon Biru (BCC) dengan fasilitas dana hibah dari Milenium Challenge Account Indonesia (MCAI).

Wibowo, 2015, Pendidikan Karakter Berbasis Kearifan Lokal di Sekolah, Yogyakarta, Pustaka Pelajar.

\section{Buku}

Ardianto, Elvinaro, 2007, Komunikasi Massa Suatu Pengantar, Bandung: Simbiosa Rekatama.

Creswell, John W, 2018, Penelitian Kualitatif dan Desain Riset, Memilih di Antara Lima Pendekatan, Pustaka Pelajar, Yogyakarta.

Kuswarno, Engkus, 2009, Metode Penelitian Komunikasi Fenomenologi: Konsep, Pedoman, dan Contoh Penelitian, Bandung: Widya Padjadjaran.

Koentjaraningrat, 1990, Pengantar Ilmu Antropologi, PT Rineka Cipta.

Martono 2010, Metode Penelitian Kuantitatif. Rajawali Pers. Jakarta.

Suharto, Edi, 2006, Analisis Kebijakan Publik: Panduan Praktis Mengkaji Masalah dan Kebijakan Sosial, Alfabeta, Bandung.

, Membangun Masyarakat Memberdayakan Rakyat: Kajian Strategis Pembangunan Kesejahteraan Sosial dan Pekerjaan Sosial, Alfabeta, Bandung.

\section{Artikel Jurnal di Situs Web}

Soegondo, 2000, Membangun Indonesia Makmur dan Mandiri Berbasis Sumber Daya Alam, https://www.umi.ac.id/wp-content/uploads/2016/11/orasi-ilmiah-optimalisasi-sumber-dayapesisir-dan-laut-melalui-pembangunan-perikanan.pdf

\section{Buku Terjemahan}

Cohen, W.M. dan Levinthal, D.A. (1990), Absorptive Capacity: A New Perspective on Learning and Innovation, Administrative Quarterly, Vol. 35, 128-152.

Joel M. Charon Ten Questions, 2012, A Sociological Perspective, 8th Edition, Publisher: Cengage Learning.

Partha D., dan Ismail S. (2009), Social Capital A Multifaceted Perspective, Washington DC: The World Bank. 